TTR

Traduction, terminologie, re?daction

\title{
Said Writer to Reader. Translation as Lignification
}

\section{Barbara Folkart}

Volume 12, numéro 2, 2e semestre 1999

Poésie, cognition, traduction II - Autour d'un poème de W. H. Auden

Poetry, Cognition, Translation II — On a Poem by W. H. Auden

URI : https://id.erudit.org/iderudit/037374ar

DOI : https://doi.org/10.7202/037374ar

Aller au sommaire du numéro

\section{Éditeur(s)}

Association canadienne de traductologie

\section{ISSN}

0835-8443 (imprimé)

1708-2188 (numérique)

Découvrir la revue

\section{Citer cet article}

Folkart, B. (1999). Said Writer to Reader. Translation as Lignification. TTR, 12(2), 83-115. https://doi.org/10.7202/037374ar
Résumé de l'article

Les Trois compagnons. La traduction comme lignification - Alors que le propre du discours poétique réside dans son inauguralité, le poème traduit manifeste une tendance très nette à régresser au déjà-dit. Cette lignification résulte du parti pris de replication qui est celui de la vaste majorité des traducteurs. Il en va de même des théoriciens : rivée sur l'original, la théorie n'a que trop tendance à s'enliser dans des descriptions du texte de départ qui se veulent plus ou moins exhaustives mais qui constituent en fait une espèce d'asymptote irréalisable et ne disent strictement rien sur la production du texte à venir.

Face à cette démarche réplicative et analytique, centrée autour du lire, je propose - traductions à l'appui - une théorie et une pratique qui privilégient l'écrire.
Tous droits réservés (C TTR: traduction, terminologie, rédaction — Les auteurs, 1999
Ce document est protégé par la loi sur le droit d'auteur. L'utilisation des services d'Érudit (y compris la reproduction) est assujettie à sa politique d'utilisation que vous pouvez consulter en ligne.

https://apropos.erudit.org/fr/usagers/politique-dutilisation/ 


\section{Said Writer to Reader. Translation as Lignification}

\section{Barbara Folkart}

Le passé ne saurait être sacré. [...] Fini l'assassinat massif du temps présent!

Paul-Émile Borduas et al, Le Refus Global

[Le texte obsessionnel] se structure en clichés et stéréotypes culturels et moraux; ce qu'il faut relier d̀ un désengagement du corps dans l'énonciation obsessionnelle [...] Ainsi, l'énoncé stéréotypé qui forme un texte sans corps constitue l'un des critères distinctifs par quoi l'écrivance s'oppose à l'écriture.

Jean-Michel Ribettes

Where poetic discourse is inaugural, lignification (to borrow JeanClaude Michéa's brilliant neologism) is the process through which living, breathing language hardens into fossilized remnants of itself. This process of fossilization is in itself an inevitable stage in the life of language. Innovative uses of language invariably get standardized and absorbed into the already-said : the novel becomes the expected, then declines into cliché.

Cliché, then, is merely a stigmatized subset of a much larger category, the already-said. And the already-said is a functionally indispensable link between the virtually unlimited generative potential of the system (Maurice Pergnier's term for the closed set of abstract underlying relationships that structures all the configurations actualized or virtual - recognizable as well-formed manifestations of a given language) and the actual utterances produced by individual 
language users at any given instant. The already-said, or norm, or idiom, in other words, is the social sandwiched in between the universal and the individual; it plays the role of charnière in a three-tier model analogous to those that have been so productive in structuralist linguistics (Coseriu), translation theory (Pergnier, Toury), and what might be referred to as "subject theory" (Folkart forthcoming) :

\begin{tabular}{|l|l|l|l|l|}
\hline & Coseriu & Pergnier & Toury & "Subject theory" \\
\hline General & - langue & - systeme & $\begin{array}{l}\text { - general } \\
\text { translability }\end{array}$ & $\begin{array}{l}\text { - general concept of } \\
\text { subjectivity }\end{array}$ \\
\hline Social & - norme & - idiome & $\begin{array}{l}\text { - optimal } \\
\text { translability }\end{array}$ & - collective subject \\
\hline Individual & - parole & - message & $\begin{array}{l}\text { - actual } \\
\text { translability }\end{array}$ & - individual subject \\
\hline
\end{tabular}

This model is of course applicable to any patterned social practise. Idiom, in the extended sense, is the already-perceived, the already-conceptualized, the already-said, the already-done - a collective repertory of patternings that serve as templates for future discourse or doing. And within any given practise, the idiom itself is a stratified, multiple layering of conventionalized patternings (ipercodifiche, to use Eco's term) built up on the patterns comprising the stratum just below (Folkart 1991, p. 268 seq). Prosody, to take just one strand, feeds on the phonetic and rhythmical patternings afforded by the language (system and idiom); poetic forms build on prosodic patternings; genres and intertextualities arise out of classes of specimens actualizing those forms; dictions evolve out of intertextualities, and so forth. And all these patternings of patternings - manifesting the expectations relating to image-fields, lexical fields, emotional stances, world views and the like - form the idiom out of which poems get written, at any given time.

Of crucial interest are the dynamics of the three-tier configuration. When language (or any other social practise) is functioning productively, there is a fast feedback loop between utterance and idiom, and a far slower feedback from utterance to system, via the idiom. Perhaps the most crucial aspect of this dynamic configuration is that the already-said is the raw material for new utterances. Even the most stigmatized facets of the already-said can serve as raw material : Flaubert added value to his ramassis d'idées 
reçues by organizing them into that wonderfully caustic "dictionary" of his, much as the contemporary installation artist will use slabs of decaying meat or old tin cans rescued from the garbage heap. When language is alive, the idiom (whether in Pergnier's strictly linguistic sense or in my own, multi-layered extrapolation of the concept) is freely used, and played around with - neither enforced (as the language police try to do), nor reverenced (as the purists do), nor repeated (as the advocates of grainy translation would have us do). What counts, then, is, not the raw material itself, but what the language user - speaker, writer or artist - does with it. Meaningful discourse always transcends its raw materials, sometimes even fights against them. Poetry, in particular, tends to play in the space between idiom and system, tapping into the not-as-yet-conventionalized potential of "possible language".

And what the creative language user does with the raw material at her disposition will of course be resorbed into the idiom. One inevitable consequence of the feedback from utterance to idiom is the ongoing lexicalisation of the innovative, which ceases to be new and itself becomes fodder for further use and innovation. ${ }^{2}$

When for some reason the feedback from utterance to idiom breaks down, repetition overrides innovation, language use loses elasticity, lignification sets in. The utterance goes no further than the idiom, regresses to the already-perceived, the already-conceptualized, the already-said. It is for this class of phenomena that I propose to reserve the term cliché, whatever the type of social practise involved. As my choice of the word "regresses" indicates, I view such practises as aberrations : cliché, for me, is an unproductive, perhaps even pathological form of repetition.

\footnotetext{
${ }^{1} \mathrm{I} \mathrm{m}$ thinking, of course, of Jean-Rene Ladmiral's le français possible.

${ }^{2}$ In painting, for example, there is a very definite "winnowing process by which a picture begins to look more like its period than like itself", Gopnick 1998 p. 77.
} 
The point at which pre-fabricated discourse becomes unproductive and gets stigmatized as cliché varies enormously with the type of language-use. Poetry is hugely intolerant of the already-said. Yet highly standardized, inelastically defined concepts, terminologies and phraseologies are the stock in trade of scientific discourse. ${ }^{3}$ And in the purely "social" uses of language the most threadbare commonplaces are the most effective : it's phatic babble that enables people to survive in a roomful of total strangers.

The already-said, in a word, is both the necessary substratum for communication, innovation and knowledge, and a potential obstacle to communicating, innovating or knowing. Pushed beyond the limit where it is necessary to avoid information overload, reliance on the already-said becomes distinctly pathological.

Translation, of course, has an intimate relationship with the already-said. This is inevitable, and legitimate, since the already-said is by definition its point of departure. Far less legitimate is the mindset that continues to pervade the field : what Jacques Brault so aptly referred to as l'épistémologie du pareil au même reigns virtually undisputed, driving nearly all practise and, implicitly or explicitly, a significant amount of theoretical discourse. Outcome, according to this mindset, is measured by the extent to which the target text "repeats", or replicates, the source text; for the more naïve, congruence with the source text is somehow expected to go hand in hand with congruence with the expectations codified in the target-language idiom.

And what gets repeated, more often than not, is the epidermis of the source text : much of the translation that's done professionally is so word-bound it's difficult to break through to the referents.

\footnotetext{
${ }^{3}$ Note, though, how innovative and pleasure-full the idiom of contemporary scientific discourse is. As if to compensate for the abstruseness and the inelasticity of their terminologies, scientists have a fondness for the playfully low-brow : where Auctoritates in the non-sciences have been known to envelop the most trivial, tired, trite-and-true remarks in pompously inflated terminologies, the particle physicists and the astrophysicists are busy formalizing the universe in terms of entities such as WIMPs and MACHOs.
} 
Professional translators can be so cut off from the real of the texts they work with that they produce stunted and meaningless utterances. Sheila Fischman, grappling with a text she hasn't understood, renders Brault's key expression l'épistémologie du pareil au même by the precooked dictionary equivalent "six of one, half-a-dozen of the other" blithely unaware that she is enacting precisely what Brault was railing against.

In extreme cases, the ideal of repetition takes a distinctly bizarre turn. Michèle Bourjea offers us an ethereal version of Bouvard and Pécuchet settling down to the hugely satisfying task of copying : the kind of translation she praises is fatale réduplication, pur phénomène de mimétisme; le traducteur, she writes, suit les mots à la trace [...], avec l'application d'un enfant qui décalquerait un dessin, [...] comme qui infiniment copierait (Bourjea 1986, pp. 264265; see also Folkart 1991, pp. 404-407).

Sometimes repetition gets tarted up as respect for the otherness of the foreign culture, acquiring considerable moral superiority in the process, and a rich set of ideological resonances. Much has been made of close-to-the-grain translation in the last couple of decades, with exponents of foreignizing taking the naïve view that replicating the linguistic micro-structures of the source-text will somehow give the target reader a way in to the alterity of the Other. Berman première manière went so far as to say that une traduction qui ne sent pas du tout la traduction est forcément mauvaise (1984, p. 247). Jean Louis Laugier's pitch for grainy translation, predicated exclusively on micro-structural elements, looked to the lofty ideal of $i l$ nagea à travers la rivière (Laugier 1973, pp. 30-31 and Folkart 1991, p. 303).

But the way the raw material itself is structured is artistically next to irrelevant : its grain is of interest only for what the artist can do with it - Emily Dickinson making a radical new music of her own with the skip-rope prosody of the Congregationalist hymnbook. When, in fact, the competent translator chooses to render certain segments close to the grain (see Berman's example of l'air du matin a de l'or dans la bouche), he is making creative use of his own language, extending his own idiom, actualizing le français potentiel (Ladmiral), rather than replicating the micro-structures of the source text. Grainy 
translation, as far as I'm concerned, is so patently untenable a position that it could only have been maintained for its value as an ideological weapon.

The fact is that esthetic (like narrowly referential) information is conveyed at levels far above the grain of the text. True respect involves recognizing that what counts is the signal, not the carrier wave, what's important is what the source-language author has done with the source-language idiom and what the target-language writer will do with the target-language idiom. What matters, in other words, is le travail de l'écriture. Which is precisely what Berman, Meschonnic and, yes, Ladmiral were all talking about (Berman's lettre, his parlance, his assertion that l'auvre est un texte qui est premier dans son propre espace de langue (Berman 1985, p. 89); Meschonnic's il faut une théorie du traduire qui soit homologue à l'écrire (1973, p. 350); Ladmiral's français potentiel (1990, 1991 passim)) - and something like what I mean when I speak of writerly translation.

Even the focus on textual patternings, as opposed to the sense of world and the sense of work behind the text, can lead to artistically inadequate results : fixating on the already-said is no way to produce a translation that will in itself have value as a piece of writing. True admiration for the source text, true openness to otherness, involves recognizing the full of the text - the creative forces innovating in the author's use of the source-language idiom, the pulsions and dynamics at work before and behind the finished product, the forces that come into play in making text.

The fact is that texts, whether scientific or poetic, have to be made in the target language, written and re-enacted, rather than replicated, or repeated. It's no use uttering rigid edicts, like Jacqueline Risset's pronouncements to the effect that it is impossible d'implanter la tierce rime dans une traduction moderne (Risset 1985, pp. 16-17) when English language poets like Peter Dale and Robert Pinsky are out there doing Dante in terza rima, and a French poet willing to cut loose from the already-done could also do it (l'intraduisibilité est historique, et contingente, as Meschonnic long ago pointed out).

Competent translation, then, is never a matter of repetition. Whether you're working at the scientific or the poetic end of the textual 
spectrum, thinking translation is always a matter of doing, of writing out of your own understanding of the text. The thinking translator does as (not what) the source-language author did.

I'd like now to illustrate these reflections with a case study based on W. H. Auden's poem "The Three Companions", a text which is rapidly becoming famous (if not a topos) in the world of translation studies on account of the derived texts - both critical discourse and actual translations - which it has generated in recent years. I'll be examining this constellation of texts with a view to determining how the derived texts relate to both the source-text and the various strata of the target-language idiom - in a word, how the theorist and translators positioned themselves with respect to the already-said and, even more importantly, with respect to the poem yet to come, par rapport à l'àdire. I'll also be illustrating the "writerly" approach to translation, with my own renderings of Auden's poem.

First, the source-text :

The Three Companions

"O where are you going?" said reader to rider,

"That valley is fatal when furnaces burn,

Yonder's the midden whose odours will madden,

That gap is the grave where the tall return."

"O do you imagine," said fearer to farer,

"That dusk will delay on your path to the pass,

Your diligent looking discover the lacking

Your footsteps feel from granite to grass?"

"O what was that bird?" said horror to hearer,

"Did you see that shape in the twisted trees?

Behind you swiftly the figure comes softly,

The spot on your skin is a shocking disease."

"Out of this house" - said rider to reader

"Yours never will" - said farer to fearer, 
"They're looking for you" - said hearer to horror As he left them there, as he left them there.

- W. H. Auden

(from "The Orators", October 1931)

This is a piece which, rather than conveying huge cognitive or emotional insight, impresses us above all by its linguistic virtuosity, as language pleasure. What captivates us is what Auden has done with his raw material, how he's used the possibilities afforded by the English language, exploiting the virtualities of the system and all the strata of the idiom, from the purely linguistic to the prosodic, generic and intertextual. Perhaps the most striking aspect of the work of poeming is the way Auden has used sound to induce meaning, relying on the umlaut mechanism to set up two opposed systems of actant-antagonists (Reader vs Rider, Fearer vs Farer, Horror vs Hearer) and sketch in the backdrop against which he puts them through their paces (midden'madden, etc). The work of the poem also shows up in the tension Auden has created between what he has to say and the prosody he's chosen to say it in : the bouncy dactyls, like the Oh and Said $X$ to $Y$ patterns, are characteristic of the folksy English ballad; the alliterative layout of certain lines is reminiscent of Anglo-Saxon and Middle English verse.

Clearly, much of this play is linguistically and intertextually bound : rooted in the phonological and (inter)textual structures of the English polysystem, it is not immediately transferable into the polysystem of a romance language. Auden's, like all true virtuosity, is deeply rooted in its raw material : creation inevitably involves seeing the possibilities in the grain, and it is this that has given the poem the reputation of being intraduisible.

Like the items in the "umlaut" nomenclature, the images in Auden's poem operate at the level of induced, rather than manifest content. The "scenery" of the poem does not have an innate and inherent necessity; it lacks the stunning esthetic, cognitive and emotional impact, the heart-stopping truth-value of the imagery one finds in others of Auden's poems (for example, in number 27 of the Selected Poems) : 
Look, stranger, at this island now

The leaping light for your delight discovers,

Stand stable here

And silent be,

That through the channels of the ear

May wander like a river

The swaying sound of the sea.

Here at the small field's ending pause

Where the chalk wall falls to the foam, and its tall ledges

Oppose the pluck

And knock of the tide,

And the shingle scrambles after the suck-

ing surf, and the gull lodges

A moment on its sheer side.

Far off like floating seeds the ships

Diverge on urgent voluntary errands;

And the full view

Indeed may enter

And move in memory as now these clouds do,

That pass the harbour mirror

And all the summer through the water saunter.

November 1935

With poetry like this, we're on sacred ground. This is carnal knowledge of the world, the flesh of the instant made verb : this place, this instant, in the mystery of their onceness. One shouldn't even dream of translating these lines without inhabiting them. Compared with this, the images of "The Three Companions" value; they function as somewhat conventional "objective correlates" of fear, repression and anxiety. What's more, these manifest scenes are fear, repression and anxiety forced through severe language constraints : writing is always a dialectic struggle between the psychic contents to be projected and the demands of the raw material, and in this case the constraints of form and phonetics are particularly draconian. These, then, are archetypal, not referential images; as such they are interchangeable with whatever scary, dysphoric images the target-language writer can dredge out of her own psyche and force out of her own language. 
Ideally, the person making a French poem out of Auden's poem would be able to "shift scenery" and exploit the native possibilities of French, the succulence of the language in a manner that's analogous to the way Auden was playing around with English. The target-language poet, in a word, will (re)enact, rather than "replicate" the source-language poem - another case of the principle that the target-language poet will do as, not what, the source-language poet did.

\section{The first derived text : Jean Lambert's clichage}

Chronologically speaking, the first of the texts derived from Auden's poem is Jean Lambert's denotational "replica" :

"Où vas-tu donc? dit le lecteur au cavalier, La vallée est mortelle quand les fourneaux brûlent, Le fumier s'y entasse et ses odeurs affolent, Ce trou est une tombe où reviennent les forts".

"Et crois-tu donc, dit le craintif au voyageur, Que tu vas atteindre le col avant la brune, Que ton œil diligent va découvrir le vide Reconnu par tes pieds entre l'herbe et la pierre?"

"Quel était cet oiseau? dit l'horreur à l'oreille, As-tu vu cette forme entre les arbres tors?

Cette ombre te poursuit, silencieuse et rapide, La tache sur ta peau est un mal scandaleux".

"Va-t'en d'ici", dit le cavalier au lecteur.

"Les tiens, jamais", dit le voyageur au craintif.

"Ils ne cherchent que toi", dit l'oreille à l'horreur.

Comme il les laissait là, comme il les laissait là.

(after Brisset 1980, p. 141)

This is a translation driven by the notion of "fidelity", in the narrowest, most reductionist sense of the word, translation as clichage of the source-text's denotations. It is in no sense of the word a poem : all the virtuosity, all the gothic feel and music are gone. Even aside 
from the glaring inaccuracy of " $\mathrm{Vat} t$ ' en d'icl", it is unsatisfactory even as a replica. The pattern $\operatorname{dit} X \grave{a} Y$ is intertextually inoperative, with few if any resonances within the French polysystem. Choosing equivalents for the names of the actants on the basis of their semantics is no way to "replicate", let alone (re-)enact the poem. The items in Auden's nomenclature were chosen for their sounds. The meanings came after, an artifact of the soundplay. Sound, not the immediate semantics, should have been the most important consideration in constructing a target-language nomenclature.

Lambert's translation would work fine as an adjunct to the original in a bilingual edition designed to draw the reader into the original English text. But - whatever value they may have as ways in to the original - lacklustre, flattened out, un-virtuosic, unwriterly renderings such as this - renderings from which all the wit and play have leaked out - bring nothing new to the French language or reader. Such traductions-introductions are effective tools to help the partially bilingual reader gain a footing in the original, or its linguistic substratum, but they convey precious little of Auden : they are "beside the point".

Lambert has succeeded here in making a lead casting of Auden's language play, stripping it down to its lowest-commondenominator denotations, then forcing it into the rigid mould of the target-language idiom. In the skilled hands of Jean Lambert, Auden's travail sur la lettre regresses to the trite-and-true, the new turns into the already-said, a poem becomes a cliché.

\section{The second derived text : Annie Brisset's model}

Assuredly one of the most interesting texts derived from Auden's poem is the remarkable M.A. thesis done some years ago by Annie Brisset. It would be difficult to imagine a more skillful formalization of the poem : Brisset's text is an amazing deployment of just about every theoretical approach known to man back in 1980.

But, like all models and formalizations, Brisset's analysis has a number of inevitable shortcomings. First, and most obviously, matrices and hyper-matrices such as Brisset's are inherently inadequate to the poems they dismantle : the cost of formalization is inevitably 
reduction. Secondly, analytical models tend to have a "rigidifying" effect, imparting a patina of necessity to what may in actual fact be "sporadic" outcomes of the struggle between invention and raw material - the writer wrestling with the muscular angel of language until it blesses him with a poem. ${ }^{4}$

Some aspects of Brisset's model require so much digging out, they are so much an artifact of the critical apparatus she deploys that they jibe with nothing in a skilled reader's perception of the poem in itself. ${ }^{5} \mathrm{My}$ view is that the poetically competent reader's response to the text is a more productive matrix for generating a target-language poem than any modèle grillagé can ever be. Writing is driven by intuition - the intuition of a competent poet being a more complex, more complete, more highly organized and finely tuned grasp of what makes a poem than anything a theorist can aspire to formalize. The translator who is competent to make a derived poem can safely prefer her own instincts to any other reading, I believe. Pre-mediating one's writing through the non-internalized already-said - background reading or ad hoc academic models - is a sure way to deprive it of urgency and drive.

Most crucially of all, as far as I'm concerned, formalized models tend to deal only with what I call "the flat of the text", or "the text of the text" - the surface of the poem and its semiotic underpinnings, the different strands that give the poem its weave and texture. Such models, in a word, focus on the artifact, not the facere, on the product rather than the productivity that gave rise to it. They have nothing to say about the dynamics of poetic performance.

4 A passage such as the following seems to posit a level of conscious intentionality far beyond what's involved in wrestling a poem out of your raw material : "On se souvient que la première strophe, lieu du discours d'un locuteur fort de son savoir, manifeste une plus grande régularité des isophonies primaires que les autres strophes. La vérité y est iconisée par des structures rigides qui coïncident avec les points d'attente, sans perturbation. Les connexions phono-sémantiques ont ici des répercussions axiologiques précises, etc. 》 (Brisset 1980, pp. 165-166).

'A case in point is Brisset's assertion that "reader" is the lynchpin ("la pierre angulaire") of the poem (ibid., p. 162). 
Models like Brisset's are artifacts unto themselves : they have their own coherency and esthetics; their value resides in the cogency and elegance of their insights. But they are readerly, retro-spective, after-the-fact entities that have little or nothing to say about making text. From the creative standpoint, they are dead ends rather than points of departure. Preoccupied with the already-said, they have little commerce with the poem-to-come, the $a$-dire. Until such time as they are metabolized into an active, writerly impulsion, they have no future.

Writing, though, is future. Writing is forward moving, inaugural : there are no grids or plumb-lines chalked out in advance, no blessings or commandments, no priesties benedicting you as you push off for where you've never been before. What interests me far more than the already-said poem is the productivity that gives rise to poems - the full of the text, the proactive pulsions and forces that drive it into being.

If I can use shorthand, one of the intuitive, pro-active, "making" forces that drive the poem into being is "ear", or "instinct". The difference between the way a critic dismantles a poem and the way a poet writes one is analogous to the difference between a formalized grammar and the dynamic intuitions of a native speaker : oreille, as Gustave Guillaume pointed out, is invariably a whole panoply of internalized rules. Some of these rules, he might have added, although empirically operational, remain beyond the purview of formal analysis at any given time. I'm not for one instant suggesting that "ear", "instinct" or "intuition" constitute a mystical-mushy savvy different from what analysis can get at, after the fact. Ultimately, the proactive, writerly forces work on the same material that retroactive analysis will later partially bring to light : "expert programs", in fields such as medicine, are analytical attempts to break down and formalize the savvy of skilled practitioners. And there is no doubt in my mind that the writerly impulsion is enriched by whatever type of analysis it has been able to absorb : "intuition" must constantly be updated. What I am saying is that "ear" and "instinct" constitute a more direct, less mediated, more agissante, pro-active and dynamic command of the material with which all artists work. Intuition, in a word, is the intellectual fast track. 
Where analysis is retroactive, and readerly, feeding on the already-said, writing is pro-active. Nowhere are the limits of analysis demonstrated better than in the two translations Brisset herself proposes. Where Brisset's programme translatif is resolutely normative and replicative - what she articulates, in this thesis, are demands, not desiderata - these demands are instantly wiped out by the compromises and insufficiencies of the two lacklustre target-texts that finally emerge after so much brilliantly analytical discourse. ${ }^{6}$

\section{Derived texts from the CATS workshop : translations, commentaries and a translator's journal}

Nearly twenty years after producing that remarkable M.A. thesis, and in its wake, so to speak, Annie Brisset had the idea of organizing a workshop, as part of the International Colloquium on Poetry, Cognition and Translation held in Ottawa, in May, 1998, under the auspices of the Canadian Association for Translation Studies (CATS). She invited a panel of six translators and academics to prepare and present their own renderings of Auden's poem into French. Two of the participants limited themselves to providing critical feedback; one participant (himself the author of several published collections of poetry) read a translation in rather lumpy (sprung?) alexandrins, which he promptly boiled down into a sort of concrete poem. The three remaining participants produced translations in alexandrins with mid-line cesuras (at least one of these texts was half-rhymed); one of the participants also read from the translator's log she'd kept as she worked on Auden's text. I haven't seen transcripts of these texts, so I'm obviously not in a position to discuss details. What interested me most, in any case, was the approach that seemed to be embodied in both the translations and the discussion.

\footnotetext{
${ }^{6}$ Brisset's renderings appear on pages 169 and 179 bis of her thesis - and Brisset herself is the first to acknowledge their shortcomings. Other analysts are less cautious, less esthetically aware : the discrepancy between the grandiosity of their analysis and the meagreness of their results (the mountaingiving-birth-to-a-mouse effect) is symptomatic of the huge bias towards reading over writing (and towards the source text over the target text) which marks so much of the work done in the field of translation studies.
} 
The first thing that caught my attention was the way one of the participants had prepared herself to tackle the source-text by backing off from it, reading round it in ever widening circles - first the entire collection of poetry, then additional materials by and about Auden and then making inventories of the different contexts in which specific words occurred, etc. : in a word, burrowing back into the already-said rather than coming to direct grips with the poem, on his terms and hers. (Ironically, what she uncovered, at the end of all her reading and rereading, was the fact that Auden seems to have despised... reading). This translator's remarks had little if anything to do with the actual business of making text: I can't recall any comments about choices of metre or rhyme scheme, ways to get rhythms going or set up internal rhymes, types and quality of rhymes, strategies for building in sound play or setting up patterns that would repeat from line to line and verse to verse, strategies for making décor, or scenery, in her poem. Her remarks were almost entirely retrospective, fixated on the alreadysaid, the poem that was there before she even set to work.

Even more striking, I found, was the way the actual translations presented at the workshop regressed to the idiom, recasting Auden's travail de la lettre in the canonical prosodics and esthetic expectations of the target system. In a culture which no longer practises regular poetry to any great extent, the instinctive reaction, if you're not used to handling formal prosody and want your translation to be seen to be poetry, is to go for the alexandrin. ${ }^{7}$

\footnotetext{
${ }^{7}$ An extreme case of this tendency is the collection of poems excerpted in a recent issue of the Revue de l'École Centrale Paris. One distinctly Baudelairian stanza will be enough to demonstrate the regression to the idiom (diction and prosody) : Le khôl, recueilli de son étui d'argent,/Dessinait, de ses yeux. l'attrait de puits charnels./Le musc et l'ambre jaune embaumaient tout son être./L'or et l'argent, précieux, enjolissaient son corps.
} 
But for me the most illuminating moment of the entire workshop came when I suggested that eight or ten-syllable lines (abundantly represented in Middle French lyric poetry, for example) might be used, rather than the alexandrins all three translators had gone for - and was told by all three in unisson that the shorter line would make it impossible to fit it all in - "it", or "tout", being of course the already-said surface of Auden's poem, its pre-existing textual structures. Cramming it all in - even when it willingly accommodates padders like l'immonde donc - is as clear a formulation as one could wish of the ethos of repetition : clearly, these translators saw it as their goal to clicher the source-text as closely as recourse to the idiom of (past) French poetic practise would allow them to. ${ }^{8}$

I haven't yet seen the tapes that were made during the workshop, so I can't reproduce here any of the translations read on May 30 . What I can say about them is that by and large they struck me as being more aware, more skillful, and generally more "accurate" renderings than Lambert's - more refined outcomes, in a word, of what was nonetheless pretty much the same approach. These were all competent traductions-introductions that would give the Francophone reader a way in to the original. I think it's fair to say that none of them, though, were traductions-textes, or freestanding poems.

Traductions-introductions tend to be accompanied by stock formulas about the woeful inadequacies of the target-text, the impossibility of ever matching the miraculous perfection of the sourcetext. To these canonical lamentations I' $m$ tempted to respond : why don't you try writing a target-language poem - or at least let someone else try?

I'd like now to demonstrate an alternative approach to the practise and theorisation of translation - a pro-active approach, one that emphasizes writing, rather than reading, l'à-dire rather than the déjà-dit, the poem-to-come, rather than the one that's already there.

${ }^{8}$ Brisset, too, seems to make a point of replicating the entire grid of features she has constructed : maintien de toutes les structures précédemment dégagées (p. 170); restituer toute la densité sémantique du TD (p. 153). 
The name of the game, as far as I'm concerned, is to write a targetlanguage poem, as opposed to repeating the source-language poem.

From Auden's "Three Companions" I've derived several pieces of my own, using the metres that occur most frequently in the Middle French poetry with which I'm familiar, the eight and the tensyllable line. The two that came to me first were resolutely nonreplicative (their title, incidentally, is a play on the English dictum Misery loves company - which may well have been the matrix for Auden's title, "The Three Companions") :

vers octosyllabiques rhyming abab :

\section{Les Trois Miséreux}

"Où vas-tu, Veilleur? crie le Veule, La lande, là-bas, est pestilente, la lune y luit comme la prunelle opaque d'une âme malévolente."

"Pourquoi, Actif, s'écrie l'Assis, t'éloignes-tu de ton foyer?

Déjà, autour des grands fossés

les loups commencent à tournoyer."

"Sais-tu, Mage, dit le Morfondeur que l'œil béant de Dieu te guette pour punir, dans les profondeurs, ta soif de science et d'enquête?"

"Loin de toi, Veule!" répond Veilleur, "Pour vivre, Assis!" réplique Actif, "Au diable! crie Mage au Morfondeur, Je n'ai que faire de vous, chétifs..."

"metrically correct" variants :

I. 2 Là-bas, la lande est pestilente

I. 3 luit - louche prunelle

I. 4 d'un fou / d'un œil malévolent

IV.4 Je m'en vais loin de vous 
vers décasyllabiques rhyming abab (aaab in verse 4) :

Les Trois Miséreux

"Où vas-tu, Voyageur? s'écrie le Veule, Là-bas, à l'est, la lande est pestilente, la nuit t'y nuira : comme un grand linceul elle s'abattra sur toi, silente et lente."

"Pourquoi pars-tu, Passeur? demande la Peur, N'entends-tu pas ces cris dans la forêt?

Dans chaque clairière un bâcher se prépare :

les flammes réclament tes os à dévorer."

"Méfie-toi, Randonneur! dit Repentir, Ce territoire est traitre, plein de trous, spongieux, labile, habile à engloutir les glorieux - sans trace, et d'un seul trait."

"Loin de tes veuleries!" crie Voyageur, "Pour effacer ta face!" répond Passeur, "Mes pieds sont clairvoyants!" rit Randonneur, ivre déjà du vin de l'avenir.

"metrically correct" variants :

II.1 demande Peur

II.3 Dans chaque allée / Près du calvaire

II.4 les flammes cla(ment) leur dú à dévorer

Since this was to be my verse, I felt free to make all sorts of technical choices. I've rhymed as richly as possible, for the sheer pleasure of rhyming (Morfondeurlprofondeurs, forêt/dévorer; pestilente/silente et lente, and further on, farfadets/échafaudée). I've used lots of slant rhymes (assis rhymes with fossé, Peur with prépare) - not because they offer an easy way out but because I love the slightly dissonant music they make. (Whether or not such rhymes 
are as effective in French as they are in English remains to be seen). I felt no qualms whatsoever about resorting to rimes pour l'oreille (e.g. singular to plural, when the difference is inaudible), or even what I like to call "mind rhymes" (slant rhymes playing voiced and unvoiced phonemes against one another, as in Bourgeois/choir, below). I've beefed up the end-rhyme scheme, once again for the sheer pleasure of rhyming - an instinctive compensation for the loss of mid-to-end rhymes like midden/madden. I've tried to keep my diction "clean", avoiding anything that might sound stilted or mannered : kitschy inversions were out - I wouldn't be caught dead writing things like les grands hommes morts par la terre avalés, even though it would have given me a strong rhyme with la vallée.

When it suited me, I availed myself of the $e$ muet (Prudence, Bourlingueur, below) : the prosodic stratum of the idiom is there for the plundering. But by and large my scansion is that of the spoken language : la lande, là-bas counts for just four syllables. I could easily have readjusted the line so that it would scan out, conventionally, as eight syllables (là-bas, la lande est pestilente), but the rhythm of my line would have been less satisfactory, and rhythm is what counts, not scansion - assuredly not the fossilized remains of speech rhythms that died out a century or more ago. The feedback loop from utterance to idiom operates at every level of the idiom; prosodic conventions tend to lag behind, but are periodically brought up to speed. Cleavages between poetic practice and the living language drag the poem back into mannerism and cliché : English poetry really put its house in order, at the beginning of this century, by booting out the last remnants of a Victorian poetic diction that lagged behind the living usage. Were French poetry to do the same, we might well see regular forms once again fruiting as productively as free verse.'

Obviously, as a non-native speaker of French, I may well be unaware of any bourdes and infelicities I've committed. And even aside from such gaffes, I have a number of faults to find with my renderings qua renderings. For starters, loaded items like Veule, Actif vs Assis, Morfondeur bring the "ideology" of the text far too close to

\footnotetext{
${ }^{9}$ The precedent is, of course, Ezra Pound giving English prosody a new lease on life by roughing up T. S. Eliot's iambic fives, on the mss of The Waste Land - a job which remains to be done for the French alexandrin, as far as I can see.
} 
the surface (though, if the truth be told, two of Auden's own items Fearer, Horror - are ideologically transparent). Yet another shortcoming is my inadvertent omission of the inhibiting antagonists in the last verse of the "ten-syllable" version (I consider this less annoying than the loaded designations, since the aim was to write, not to match, and it was the sheer pleasure of versifying that made me miss out Veule, Peur and Repentir). From the far more serious standpoint of how my texts work as freestanding verse, my "ear" tells me that my texts are not as convergent as I'd like them to be. True, the last line of the "ten-syllable" version really ties it together, but I don't have a good enough sense of the target system to know whether ivre déjà du vin de l'avenir is a cliché or not. ${ }^{10}$

On the more positive side of the ledger, the "liberties" I've taken with the designations of the protagonists are all the more justified in that the operational meaning of all these terms is an artifact of the poem itself, induced by sound play. Pretty much the same remark applies, mutatis mutandis, to the "liberties" I've taken with the scenery, whose manifest content I consider a free variant to be actualized musically, and affectively, rather then denotatively. And, still on what I hope is the positive side of the ledger, I've tried to make the most of the native textures of the French language by using "overlapping", or "imbricated" rhymes such as les flammes réclament, labile habile, la lande est pestilente, etc. Finally, I hope to have added value by writing from just outside the target language - bringing the esthetic reflexes of an English-language writer to these poems I've derived in French English poetry, as Berman correctly pointed out, being coarser, far less quintessenciée than French.

What my renderings also illustrate, I believe, is a sort of openended productivity - the potential for the endless pleasures of making text. The algorithm I used to generate the four stanzas in each of the above versions could readily be used to generate expanded versions five five-line, or six six-line stanzas, and so on, set up along the following lines :

"Tu songes creux, Rêveur! crie Crève-Cœur,

${ }^{10}$ A considerable part of Brisset's elaborate analysis was in fact about the way Auden's poem converges to its end : my ear tells me she was right. 
Tes mots sont frêles comme farfadets.

La vérité est ceinte de fer, bardée, butée, échafaudée

par ceux qui ont les pieds sur terre."

"metrically correct" variants :

1. Tu mens, Rêveur! crie Crève-Cœur,

2. Tes faits ne sont que farfadets

3. La vérité se ceint de fer -

Yet another possibility would be to build in a certain amount of intertextual play, as in the following stanza, whose matrix is Baudelaire's beautiful line Ah! ne jamais sortir des Nombres et des Etres (Baudelaire is clearly not a good match with Auden's folksiness - but then the whole idea is to build a poem that stands free, not one that matches, or "repeats" the original) :

"Prudence, Bourlingueur! dit le Bourgeois,

Ne sors jamais des êtres et des nombres:

qui fréquente l'infini finit par choir

pris de vertige, les yeux rongés par l'ombre."

"metrically correct" variant :

Qui vise l'infini / vit dans l'infini

(The choir that rhymes richly with Bourgeois, in this verse, like the pestilente of the first two versions, points to the possibility of indulging in the pleasures of diachrony; in one of my later translations, I used the succulent cherras instead of the back formation chuteras.)

Above all, I want to stress that my renderings embody instinctive choices. When I speak of making the most of the native textures of the French language, or building in intertextuality, I'm talking after the fact. The translation of poetry, for me, is very much a matter of ear (in Guillaume's sense of the word) rather than analysis; to work best it has to stem from the translator's gut reaction to the source poem. Intuition is a function of experience, and gut reactions may in fact be based on a good deal of metabolized theory and criticism 
(clearly, my own take on Auden's poems has been influenced by the fact that I read Brisset's thesis years ago, with enormous admiration, and have perhaps been mulling it over in the back of my mind ever since) - but they nonetheless kick in sponte sua.

All in all, then, I think my translations, whatever their shortcomings, can have a programmatic value, as illustrations of how to write, in the target language, a poem that will have something of the feel of the original, rather than trying to repeat the source-language poem, or kowtowing to all the strictures of the target-language idiom (dictions, image-fields, lexical fields, prosodies - in a word, the prevailing esthetics).

My approach involves appropriating both the source text and the target idiom, treating the multiple layers of the idiom as raw material that is mine - every last layer of it - mine to do with as I want." The game is to create a poem that will be sufficiently textured to arouse the reader's interest as a bizarrerie in its own right, a piece of music and imagery. The textures of my renderings result from internal rhymes and alliterative lines which will work on their own, I hope, quite independently of any reference to the Anglo-Saxon or Middle English line.

As a writing subject, in short, I've rejected the canonical stance, with its reverence for the already-said, its valorisation of repetition, its emphasis on clichage. As opposed to the compulsion to cram it all in that seems to be the stock in trade of virtually all practitioners, my attitude is that there's not the slightest reason to preserve patterns such as said $X$ to $Y$, which, as recognizable folkballad markers, are part of the idiom of English verse, but have no such

"In particular, I've cut free of the already-said by refusing to conform holusbolus to the prosodic conventions stocked in the target idiom (jettisoning the conventional treatment of the -e muet). I also distanced myself with respect to the prosody of the source text : there was no reason, I felt, to preserve the symmetry of Auden's line (as in the CATS renderings, with their translatorly alexandrins split $6+6$, line after line after line). I also felt free to cut loose from folk resonances : whether those of the source text, which have no echo in French, or those of the target system, which I don't know well enough to mine for items that might "match" the folk items in the original. 
resonances in French. Nor is there any valid reason to feel obliged to conserve the order $\mathrm{X}$, then $\mathrm{Y}$, when the option of putting $\mathrm{Y}$ first, as a vocative, allows you to get rid of the syllable $a$.

What counts, in other words, is making a text that will work as a poem in the target language, rather than vainly running after what worked so splendidly in Auden's one-off language event. The target language writer doesn't have to be constrained by Auden's patternings; she should have enough momentum, enough impetus to invent patterns and imagery of her own out of an altogether different raw material. A freewheeling, writerly approach like this is the only approach that stands a chance of producing anything like a freestanding poem - and what good to the target-language reader is a poem with the wit and music leached out of it by a pedestrian and repetitive approach?

Writerly translation is radically different from repetitive, readerly translation. It demands the willingness to divorce one's self from the already-said, and the ability to generate new images - the substitution of images, in a poem like this, being analogous to the way terminologies and nomenclatures in different languages routinely select different features of the same referent to bring to the surface (disk drive vs lecteur de disque). It's altogether possible that a native speaker would have enough mastery of French (language and prosody) to produce images that were quite close to those of the original : it's well known that people translating from their strong into their weak language tend to go wider of the mark than those translating the other way around. But what counts, even when the target poem's images are quite close to those of the original, is the target-language writer's ability to impart an authentic momentum to her images, sustain them with a genuine impulsion.

Writerly translation, in a word, demands the very set of aptitudes, attitudes and skills that writers work directly out of.

Still, partly to make sure I wasn't just taking the easy way out, even more so out of a desire to challenge myself at the level of technique by working within a tighter set of constraints, I attempted a 
number of "closer" translations - ones that would deviate less from Auden's manifest imagery and would preserve the "lynchpin" Reader in the form of Lecteur. The "agonist" now becomes l'Acteur, which I quite like, since acteur, in the medieval manuscripts right through the end of the fifeenth century, designated auteur, and Gaffiot's definition of the Latin actor is "celui qui fait mouvoir, avancer, celui qui fait".

My first "replica" is in vers décasyllabiques rhyming abab (abba in the third verse) :

Les Trois Miséreux [11, p. 45 ("Auden, side by side - copie")]

"Pourquoi sors-tu? dit Lecteur à l'acteur, Le vent des fournaises, haleine mortifère, répand la folie; l'odeur des ordures

dérange les géants qui gisent sous la terre."

"Tu ne vas pas seul, dit Peur au passeur, grimper jusqu'au col entre chien et loup?

Tes pieds, sans lumière, n'y verront pas clair : la voix arrachée, tu cherras en-sous."

"Qu'est-ce qui bruit? crie Horreur à l'oreille, Les cyprès frémissent dans la brune tardive, voilà qu'elle arrive, cette ombre furtive, pour strier ta peau de stigmates vermeils."

"Lire est un leurre!" crie l'acteur à Lecteur, "Mes pieds sont sûrs!" crie le passeur à Peur, "Meurs de terreur!" crie l'oreille à Horreur, en laissant ces gueux, en laissant ces gueux

working variants :

III.3-4 tout doucement arrive une ombre furtive qui pose sur ta peau une pustule vermeille

"metrically correct" variants :

I.2 Le vent des fournais(es), souffle mortifère,

I.4 dérange les géants gisant sous terre 
III.4 de taches vermeilles

A second "replicative" translation (in ten-syllable lines rhyming abab throughout) attempted to do away with some of the remaining "inaccuracies", but introduced a few of its own :

\section{Les Trois Miséreux}

"Où t'en vas-tu? dit Lecteur à l'acteur, Des fours du val sort un foehn mortifere; vrai vent de folie, l'odeur des ordures corrompt jusqu'aux grands qui gisent dans la terre."

"Tu n'imagines pas, dit Peur au passeur, que tes pieds verront, a la nuit tombante? Atteindre le col sans attendre l'heure propice, c'est te précipiter, hurlant."

"Qu'est-ce qui croasse? crie Horreur à l'oreille, De l'arbre avorté un revenant sort, cet abcès travaille ta peau, tes entrailles, ce qui frôle ton épaule siffle et se tord."

“Assez, verbeux!" crie l'acteur à Lecteur, "Chaque jour tu meurs!" crie le passeur à Peur, "Plante là tes pleurs!" crie l'oreille d Horreur, en s'éloignant d'eux, en s'éloignant d'eux

working variant :

I.1 Du fond du val sort un foehn mortifère

"metrically correct" variants :

I.4 qui gisent sous terre

II. 1 tu ne penses pas

III.1 Qu'est-ce qui bruit? crie Horreur à l'oreille

III.4 This line is incorrigibly hypermetric : tant pis!

IV. 2 Sans fin tu meurs

IV.3 Bois donc tes pleurs! / Assez de pleurs! 
My final "replica" is as far as I'm prepared to go in sacrificing music and mood to denotation, in the name of "fidelity":

\section{Les Trois Miséreux}

“Où t'en vas-tu? dit Lecteur à l'acteur, La mort sort des fours, vidant la vallée, l'odeur des ordures répand la folie, les grands, par cet antre, rentrent sous terre."

"Tu n'imagines pas, dit Peur au passeur, atteindre le Pas avant la nuit noire?

Tes pieds démunis, n'y pouvant voir goutte, lâcheront le granite, amorceront ta chute."

"Que crie la corneille? dit Râle à l'oreille, Une ombre louche chuchote à ton épaule, dans cet arbre torve un corps se tortille, sur ta peau éclôt la fine fleur du mal."

"Loin du logis!" crie l'acteur à Lecteur, "Mes pieds pourront!" crie le passeur à Peur, "Oiseau de misère!" crie l'oreille à Râle, en s'éloignant seule, en s'éloignant seule

"metrically correct" variants :

II.1 Tu ne penses pas

II.4 hors / loin du granite

III.4 l'âpre fleur / le fleuron du mal

These "replicas", I feel, are distinctly less satisfactory as pieces of writing than my previous efforts. The cost of "fidelity" is a certain amount of syntactic monotony (dans cet arbre torve and sur ta peau éclot opening two successive lines in verse three of the last version), a loss of rhythmical momentum (I'd deliberately foregrounded the metrical grid, since I couldn't match the bounce of Auden's dactyls, but I'm not altogether happy with all those endstopped lines, split clean down the middle). The soundplay is more forced, the imagery more contrived, there seems to be an overall loss of coherency. The rhyme sounds, within some of the verses, are 
insufficiently differentiated from one another, and my rhyme scheme sometimes wanders more than I'd like it to. In short, there's an undeniable loss of imagistic impact and prosodic precision, despite the fact that I tried really hard to get these versions right, and actually had quite a bit of fun doing so. (I wasn't trying to fail at writing verse, just to prove a point of "theory".)

Nearly all the "bits and pieces" of the original are there, but redistributed and sometimes given different roles in order that the formal structures might emerge relatively uncompromized. And of course an exercize like this raises the question of just what constitutes denotational accuracy. Consider the last line of Auden's third stanza. In the pursed-lipped, mother-hennish register of Hearer's interlocutor, shocking disease is the socially acceptable way to refer to syphilis and other STDs, over tea, Tuesday afternoons, in the parsonage. Sur ta peau suppure une pustule vermeille would be far "balder", but still within the realm of denotational translation : as nice a touch as it lends to Auden's original, the mincing hypocrisy of Horror's voice is something of a free variant. Similarly, in the second verse of my first "replica", Tes pieds, sans lumière, n'y verront pas clair, / la voix arrachée, tu cherras en-sous merely actualizes the fall hinted at darkly by Your diligent looking discover the lacking/Your footsteps feel from granite to grass - an example of what Vinay-Darbelnet referred to as modulation - in a word, the sort of manipulation that even the Readers, Fearers and Horrors of translation studies can live with.

I've introduced a certain amount of intertextuality in the last of my versions, none of which has to be grasped for the poem to be operative. In verse three, la fine fleur $d u$ mal is an allusion to the interprétations syphilitiques which played such an edifying rôle in the Procès des Fleurs du Mal. The Pas in the second line of verse two, is a reference to the medieval Pas de la Mort (Auden, too, for his own personal pleasure, loaded his poetry with all sorts of mind games).

I've provided "metrically correct" variants for all six of my versions, just to make sure I wasn't trying to pass the much despised alexandrin off as a 10-syllable line, or the 10-syllable line off as an 8syllable line. The discrepancy between these variants and my original lines is particularly evident in items like comme and Crève-cour, where the niceties of prosodic convention are at loggerheads with the rhythms 
of the spoken language. Such discrepancies are indicators of lignification and fossilization : nowhere is the process of clicheformation more evident than in the way the prosodic conventions operative at any given time (word order and scansion are particularly sensitive areas) lag behind the patternings of the spoken language.

And nowhere does the artificiality of out-of-synch prosody show up more than in the treatment of the infamous $e$ muet. Prosody conveys a considerable amount of diachronic information. In scientific editions of medieval French texts, analysis of the versification - what rhymes with what, how many syllables such and such a word counts for - is a valuable tool for determining how far the language has shifted away from its Latin origins. If you look at how French scansion has evolved since the end of the middle ages, you can see the treatment of the $e$ muet periodically readjusting to catch up with the rhythms of the living language. In Old and Middle French, the desinence $-e$, in items such as amie and crie, could and often did count as a separate syllable (ami-e, cri-e) : por-tent en livré-e jolie scans one of the most celebrated poems of the $15^{\text {th }}$ century. This option was eliminated as the spoken language evolved and words like amie, crie and livrée moved further and further away from their remote ancestors amica, quiritat and liberata.

Similarly, comme was quite naturally a two-syllable word as long as the memory of its ancestor, quomo (itself a low-life deformation of quomodo) still lingered in the mouths of speakers. Who knows, in the mouths of nineteenth-century speakers, words like comme may well have still been bisyllabic in certain phonetic contexts $^{12}$ (all we know for sure is that comme seems systematically to count for two syllables in Baudelaire's poetry). But that vestigial tail has since atrophied completely, and there are whole swaths of the French-speaking world in which few pronounce comm-e, or crèv-ecour, in any phonetic context.

The speech patterns fossilized in conventional scansion are the dimmest of "race memories", language rememorating a past too ancient

12 Indeed, in Romain Rolland's Les Thibault, set in the early days of the twentieth century, the pronunciation ami-e is used to characterize one of the male figures. 
for most speakers to be aware of, with features jettisoned centuries and centuries ago leading an afterlife life of their own in the more sclerotic layers of the idiom. Nowhere does the dead weight of the already-said show up better than in the prosodic conventions governing word order and scansion : kitschy inversions (Des simples gens le désespoir, in a translation that doesn't even have the excuse of rhyming), constructions that are out of wack with the patterns of the living language, scansion that is out of synch with the rhythms of the spoken language - lignifications like these are what have given rhymed and metred verse such a bad name in the contemporary French-speaking world.

As I've been saying all along in this essay, a poet translator never has to genuflect to the more rigid prosodic conventions of the target idiom : until French prosody is willing either to operate in synch with the rhythms of everyday spoken French, or to "spring" its scansion, the way Hopkins did for English poetry over a century ago, it's going to remain lettre morte, out of touch with the language living all around and disdained by practising poets. In a word, just because regular French verse has "always" scanned that way is no reason to keep on doing it thus and so : il faut savoir tenir tête au déjà-dit.

Even so, the dead weight of the already-said kept tugging at my replicative translations. All of which proves that deriving a poem in the target language can never be a matter of finding words to squeeze pre-existing surface structures and contents into. Like direct writing, "derived writing" is very much a matter of seeing what will come out of the words, what words and patterns, images and sounds will come to you. Writing is always an open-ended undertaking (even when you're bungee-jumping with the source text as your cord - which might just be a metaphor for intelligent translation). Subordinating sound patterns and prosody to the manifest referential content of a pre-existing text is an eminently bad idea. The "gain" in first-degree semantic accuracy is not worth the loss of the poem's gothic feel and music. No poem ever lives in its denotations - especially not a poem whose sense is an artifact of its soundplay. It's worth compromising the quality of the rhyme for a fine image, but not for the sake of denotation.

My free translations were attempts to do. My stodgy translations were attempts to re-do. But if you think about it, translation 
never involves repetition - not even technical and scientific translation. Why should the translation of poetry ever be a matter of re-doing? Poems that don't arise out of an intimate compulsion fall flat.

Auden's poem was the outcome of his own personal hangups and preoccupations struggling to voice themselves against the constraints of English phonetics and prosody. Attempts to repeat it in another language are unlikely to work.

Throughout this essay I've been stressing doing as the first writer did, rather than repeating what he did. My emphasis has been on moving forward as opposed to following in the source-writer's footsteps, on writing as opposed to replicating, inaugurating as opposed to rehashing. I've been stressing the pro-active, "making" forces that drive poems into being, and defending the position that translation, too, should be making.

So much of the discourse on translation is readerly backward-looking, fixated on the already-said, dedicated to the proposition that translation must be as Faithful as possible a clichage of The Original Poem. We've all seen scholarly papers that pile up mountains of analysis, only to birth a mouse of a poem. Such essays are all reading, no writing. What they present us with are idealized, asymptotic clusters of functionally relevant features that no target text will ever fully actualize. In a very real sense, then, such models are not about translation at all. The mouse cadavers they deposit just before their end-notes and bibliography are flimsy pretexts for a display of scholarly, not writerly, skills. The very defectiveness of these murine target texts manifests the ideological given from which such papers tend to start : the inherent superiority of the original. It's time translation studies as a whole moved beyond this readerly bias (as indeed the Tel Aviv school has long since done).

Analysis, as I said earlier, when it's done with the cogency, the rigour and the wide-ranging command of critical approaches deployed by an Annie Brisset, can be an end in itself. It can go further than itself, stimulating theoretical debate, giving rise to quality critical discourse. What analysis can't do, even the best of it - and Brisset's 
unpublished M.A. thesis is superior to anything else I've seen in the genre - is flower into a target text that even comes close to working as a poem. What, after all, is the use of teasing out "isorythmies", "isophonies" and the like - only to wind up telling us that the poem can be rendered neither with alexandrins nor with ten-syllable lines, that only "vers libres" will do - and then presenting us with "vers libres" that are alexandrins ratés, conceived of in terms of "pieds" and "hémistiches"? Strictures such as these merely add another, formidably coercive, layer to the already-said. If you're clueless when it comes to writing poetry, don't tell us how it must be written. If you do happen to know how to write poetry, just do it.

Little of the canonical discourse on translation has anything to do with the actual business of making text. Nothing in it has anything to do with the pleasure of making text. Where the readerly, reverential approach stresses duty, authority, the law of the already-said, writing operates on the pleasure principle. To translate as a writer is to pleasure in the act of making text, moving forward with infinite respect for craft, technique, the possibilities of your raw material. The writerly translator saves her reverence for the poem still to come.

Université d'Ottawa

\section{References}

AUDEN, Wystan. Hugh (1989 [1979]). Selected Poems. New York, Vintage International (Random House).

BERMAN, Antoine (1984). L'Épreuve de l'étranger. Paris, Gallimard.

- (1985) "La traduction et la lettre, ou l'auberge du lointain". Les Tours de Babel. Mauvezin, Trans-Europ-Repress, pp. 31-150.

BOURJEA, Michèle (1986). “Agua Viva. Au fil des mots. Analyse critique de la traduction en français de Agua Viva de Clarice Lispector". Meta 31.3, pp. 258-271.

BRISSET, Annie (1980). Structures de signifiance et traduction. Réflexions sur un poème de W. $H$. Auden. Unpublished M.A. thesis, University of Ottawa. 
- editor (forthcoming as volumes XII.1 and XII.2 of TTR). Poésie, Cognition, Traduction.

FOLKART, Barbara (1991). Le Conflit des énonciations. Traduction et discours rapporté. Candiac, Les Éditions Balzac.

GAFFIOT, Félix (1963 [1934] ). Dictionnaire Illustré Latin-Français. Paris, Hachette.

GOPNIK, Adam (March 16 ${ }^{\text {th }}$ 1998). "The Power Critic". New Yorker, pp. 70-78.

LADMIRAL, Jean-René (1991). "La langue violée?" Palimpsestes 6, pp. 23-33.

- (1990). "La traduction proligère - sur le statut des textes qu'on traduit". Meta, 35.1, pp. 102-117.

LAUGIER, J. L. (1973). "Finalité sociale de la traduction : le même et l'autre". La Traduzione : saggi et studi, Trieste, pp. 23-32.

MESCHONNIC, Henri (1973). "D'une linguistique de la traduction à la poétique de la traduction". Pour la poétique II. Paris, Gallimard.

MICHÉA, Jean-Claude (1995). Orwell, anarchiste tory. Climats, Castelnau-le-Lez (quoted in Le Monde Diplomatique, septembre 1998, p. 32).

RISSET, Jacqueline (1985). Translation of Dante's Commedia, vol. 1, L'Enfer. Paris, Flammarion.

ABSTRACT : Said Writer to Reader. Translation as Lignification-Lignification, the degenerative process whereby language hardens into cliche and discourse remains stuck in the already-said, manifests itself in every type of language practise, from the everyday to the poetic.

Translation, by its very nature, deals with the already-said, but the relationship is all too frequently regressive, at the level of both practise and theory : hence, the empirically observable inferiority of so many 
target-texts with respect to the sources they attempt to "replicate"; hence, too, the failure of so many theoretical models to have anything whatsoever to say about the actual production, in the target language, of texts that really are texts.

This essay proposes, and illustrates, a writerly way of envisaging both the practise and the theory of poetic translation - an approach that emphasizes the writing of the target-text as opposed to the readerlyreplicative models that give priority to analysis of the already-said.

RÉSUMÉ : Les Trois compagnons. La traduction comme lignification - Alors que le propre du discours poétique réside dans son inauguralité, le poème traduit manifeste une tendance très nette à régresser au déjà-dit. Cette lignification résulte du parti pris de réplication qui est celui de la vaste majorité des traducteurs. Il en va de même des théoriciens : rivée sur l'original, la théorie n'a que trop tendance à s'enliser dans des descriptions du texte de départ qui se veulent plus ou moins exhaustives mais qui constituent en fait une espèce d'asymptote irréalisable et ne disent strictement rien sur la production du texte à venir.

Face à cette démarche réplicative et analytique, centrée autour du lire, je propose - traductions à l'appui - une théorie et une pratique qui privilégient l'écrire.

Barbara Folkart: School of Translation and Interpretation, University of Ottawa, C.P. 450, Succursale A, Ottawa (Ontario) K1N 6N5.

Courriel : bfolkart@uottawa.ca 